Pemanfaatan Tepung Tulang Ikan Patin dan Tepung Tulang Ikan Tuna - Pangestika, dkk Jurnal Pangan dan Agroindustri Vol. 9 No.1: 44-55, Jan 2021

Diterima: 08/07/2020, Direview: 03/09/2020, Diterbitkan: 30/01/2021

\title{
PEMANFAATAN TEPUNG TULANG IKAN PATIN DAN TEPUNG TULANG IKAN TUNA UNTUK PEMBUATAN COOKIES
}

\section{The Utilization of Patin Fish Bone Powder and Tuna Fish Bone Powder in Making Cookies}

\author{
Widya Pangestika*, Fitria Widyasari Putri, Kusuma Arumsari \\ Program Studi Pengolahan Hasil Laut, Politeknik Kelautan dan Perikanan Pangandaran. \\ JI. Raya Babakan KM. 02 Pangandaran, Jawa Barat 46396, Indonesia \\ ${ }^{*}$ Penulis Korespondensi, Email: widya.pangestika@kkp.go.id
}

\begin{abstract}
ABSTRAK
Limbah tulang ikan dapat dimanfaatkan sebagai tepung tulang ikan untuk bahan tambahan dalam pembuatan cookies kaya kalsium. Penelitian ini bertujuan untuk mengetahui hasil rendemen, tingkat penerimaan konsumen, kadar kalsium, serta daya simpan cookies. Penambahan tepung tulang ikan patin P1 (8\%); P2 (16\%); P3 (24\%) dan tuna T1 (8\%); T2(16\%); T3 (24\%) dilakukan sebagai substitusi tepung terigu. Cookies tanpa penambahan tepung tulang ikan $(\mathrm{K})$ juga dibuat pada penelitian ini. Dari hasil perhitungan, diketahui rendemen tepung tulang ikan patin dan tuna, masing-masing sebesar $38.6 \%$ dan 43.6\%. Tingkat penerimaan konsumen dilihat dari uji hedonik dimana diketahui bahwa cookies tanpa penambahan tepung tulang ikan $(\mathrm{K})$ adalah yang paling disukai konsumen, dengan rata-rata 7.5. Kandungan kalsium pada cookies tulang ikan patin (P1) dan tuna (T1) adalah $47.7 \mathrm{mg} / 100 \mathrm{~g}$ dan $120.2 \mathrm{mg} / 100 \mathrm{~g}$. Setelah $14 \mathrm{minggu}$ penyimpanan, diketahui bahwa seluruh parameter sensori cookies tulang ikan patin dan tulang ikan tuna tidak berubah secara signifikan.
\end{abstract}

Kata kunci: Cookies, Hedonik, Kalsium, Tepung Tulang Ikan, Uji Daya Simpan

\section{ABSTRACT}

Fish bone waste could be utilized as fish bone powder as an addition in making calcium-rich cookies. This study aims to determine the powder yield, the level of consumer acceptance, the calcium levels, also the shelf-life of cookies. The addition of patin fish bone powder P1 (8\%); P2 (16\%); P3 (24\%) and tuna fish bone powder T1 (8\%); T2 (16\%); T3 (24\%) were carried out as the substitution of flour. Cookies without addition of fish bone powder (K), was also carried out in this study. The result shows the yield of patin and tuna fish bone powder was $38.6 \%$ and $43.6 \%$ respectively. The level of consumer acceptance could be seen through hedonic test whereas cookies without the addition of fish bone powder was the most preferable of all (average score 7.5.) Calcium content in patin fish bone cookies (P1) and tuna fish bone cookies (T1) was $47.7 \mathrm{mg} / 100 \mathrm{~g}$ and $120.2 \mathrm{mg} / 100 \mathrm{~g}$. After 14 weeks of storage, all sensory parameters of patin and tuna fish bone cookies did not change significantly.

Keywords : Calcium, Cookies, Fish Bone Flour, Hedonic Test, Shelf-Life Test

\section{PENDAHULUAN}

Limbah perikanan adalah limbah yang diperoleh dari hasil pengolahan perikanan yang dapat mengakibatkan pencemaran lingkungan. Pencemaran tidak dapat dihindari jika pembuangan limbah dilakukan tanpa adanya pengolahan limbah terlebih dahulu maupun 
adanya pemanfaatan limbah. Ikan patin merupakan salah satu jenis ikan air tawar yang tinggi akan kandungan kalsium. Kadar kalsium pada tepung tulang ikan patin sebesar $26 \%$ pada penelitian Tababaka (2004) lebih tinggi dari kadar kalsium tepung tulang ikan nila yang dilakukan oleh Lekahena, Nur Faridah, Syarief, dan Peranginangin (2014) yang hanya berkisar $18.7 \%-21.48 \%$. Untuk kategori ikan air laut, ikan tuna merupakan salah satu jenis ikan yang mengandung kalsium cukup tinggi. Menurut Trilaksani, Salamah, dan Nabil (2006) tulang ikan tuna memiliki kandungan kalsium sebesar 39.24\% lebih tinggi dari kandungan kalsium pada tulang ikan tongkol dalam penelitian Deswita dan Fitriyani (2019), yaitu sebesar $14.01 \%$.

Kebutuhan kalsium untuk manusia berbeda pada tiap usia. Kebutuhan kalsium orang berumur 19 sampai di atas 65 lebih tinggi daripada kebutuhan kalsium anak-anak, yaitu 800 $\mathrm{mg} / \mathrm{hari}$. Angka kebutuhan kalsium untuk kelompok anak-anak dari umur 1-6 tahun adalah $500 \mathrm{mg} / \mathrm{hari}$, sedangkan anak-anak yang berumur 7-9 tahun adalah $600 \mathrm{mg} / \mathrm{hari}$ (Soekirman, 2004). Remaja yang berumur 10-18 tahun membutuhkan kalsium paling banyak diantara kelompok lainnya, yaitu sebesar 1000 mg/hari (Soekirman, 2004). Agar terhindar dari osteoporosis, kalsium harus tercukupi sejak usia muda, sehingga diperlukan sebuah inovasi untuk meningkatkan kandungan pada kalsium pada makanan dan dapat mengurangi pencemaran limbah pada perikanan (Adawiyah dan Selviastuti, 2014).

Banyak bahan yang dapat digunakan untuk memperkaya kandungan kalsium pada makanan. Salah satunya dari penelitian Rahmawati dan Nisa (2015) yang telah meneliti tentang fortifikasi kalsium cangkang telur ke dalam cookies. Selain cangkang telur, bahan tidak termanfaatkan lainnya yang juga tinggi kalsium adalah tulang ikan. Lestari dan Dwiyana (2016) menjelaskan bahwa tepung tulang ikan tuna dapat berpengaruh pada tekstur, aroma, rasa dan kandungan kalsium pada stick ikan. Acuan penelitian lain yang terkait yaitu dalam penelitian Kaya (2008) menjelaskan bahwa penambahan tepung tulang ikan patin sebanyak $2 \%$ dan $4 \%$ dapat berpengaruh pada kandungan kalsium dan fosfor pada cookies tulang ikan.

Oleh karena itu, pada studi ini, akan dibuat cookies kaya kalsium yang ditambahkan tepung tulang ikan patin dan tepung tulang ikan tuna. Cookies ini merupakan makanan yang dapat dinikmati oleh semua jenis kalangan usia yaitu dari anak-anak, orang dewasa, dan orang tua. Pembuatan cookies kaya kalsium ini dilakukan untuk mengurangi adanya limbah padat perikanan sambil memanfaatkan kandungan kalsium di dalamnya yang dapat dikonsumsi oleh manusia.

\section{BAHAN DAN METODE}

\section{Bahan}

Bahan yang digunakan untuk pembuatan tepung tulang ikan adalah tulang ikan patin yang berasal dari Pasar Anyar-Bogor, dan tulang ikan tuna yang diambil dari PT. Inti Mas Muara Baru-Jakarta. Bahan yang digunakan untuk pembuatan cookies adalah tepung tulang ikan patin, tepung tulang ikan tuna, tepung terigu, gula pasir, telur, choco chips, garam, mentega, bubuk vanila, dan baking powder.

\section{Alat}

Alat yang digunakan adalah baskom, panci, panci presto sendok, pengaduk, ayakan, blender, mixer, oven, loyang dan timbangan digital.

\section{Desain Penelitian}

Penelitian ini dilaksanakan pada tanggal 2 Maret 2020 sampai 5 Juli 2020. Pembuatan tepung tulang ikan dilaksanakan di di Institut Pertanian Bogor (IPB) dan Politeknik Kelautan dan Perikanan Pangandaran sementara, pembuatan dan pengujian cookies dilaksanakan di Politeknik Kelautan dan Perikanan Pangandaran dan Kota Bogor. Formulasi pembuatan cookies tulang ikan dibuat dengan menambahkan tepung terigu sebagai bahan dengan jumlah terbanyak dan beberapa bahan tambahan pembuat cookies lainnya. Penambahan 
tepung tulang ikan ke dalam adonan bertujuan untuk mensubstitusi jumlah tepung terigu. Terdapat 6 perlakuan pada penelitian ini, dimana 3 variasi adalah perlakuan dengan menggunakan tepung tulang ikan patin (P1, P2, P3) dan 3 variasi lainnya menggunakan tepung tulang ikan tuna (T1, T2, T3) sebagai substitusi penggunaan tepung terigu. Cookies tanpa penambahan tepung tulang ikan $(\mathrm{K})$ juga dibuat pada penelitian ini. Formulasi pembuatan cookies tedapat pada Tabel 1.

Tabel 1. Formulasi Pembuatan Cookies

\begin{tabular}{lccccccc}
\hline \multirow{2}{*}{ Bahan-bahan } & $\begin{array}{c}\text { Tanpa } \\
\text { penambahan/ } \\
\text { K (g) }\end{array}$ & \multicolumn{3}{c}{ Ikan Patin } & \multicolumn{3}{c}{ Ikan Tuna } \\
\cline { 3 - 8 } & $\mathbf{P 1}(\mathbf{g})$ & $\mathbf{P 2}(\mathbf{g})$ & $\mathbf{P 3} \mathbf{( g )}$ & $\mathbf{T 1}(\mathbf{g})$ & $\mathbf{T 2} \mathbf{( g )}$ & $\mathbf{T 3} \mathbf{( g )}$ \\
\hline Tepung tulang & - & 20 & 40 & 60 & 20 & 40 & 60 \\
ikan & & & & & & & \\
Tepung terigu & 250 & 230 & 210 & 190 & 230 & 210 & 190 \\
Baking powder & 5 & 5 & 5 & 5 & 5 & 5 & 5 \\
Margarin & 200 & 200 & 200 & 200 & 200 & 200 & 200 \\
Telur & 55 & 55 & 55 & 55 & 55 & 55 & 55 \\
Gula pasir & 180 & 180 & 180 & 180 & 180 & 180 & 180 \\
Ekstrak vanili & 5 & 5 & 5 & 5 & 5 & 5 & 5 \\
Chocochips & 100 & 100 & 100 & 100 & 100 & 100 & 100 \\
Susu Bubuk & 25 & 25 & 25 & 25 & 25 & 25 & 25 \\
\hline \multicolumn{1}{c}{ Total } & 820 & 820 & 820 & 820 & 820 & 820 & 820 \\
\hline Ketanyyyyyy
\end{tabular}

Keterangan:

P1 : Tepung tulang ikan patin mensubstitusi penggunaan tepung terigu sebanyak $8 \%$

P2 : Tepung tulang ikan patin mensubstitusi penggunaan tepung terigu sebanyak $16 \%$

P3 : Tepung tulang ikan patin mensubstitusi penggunaan tepung terigu sebanyak $24 \%$

T1 : Tepung tulang ikan tuna mensubstitusi penggunaan tepung terigu sebanyak $8 \%$

T2 : Tepung tulang ikan tuna mensubstitusi penggunaan tepung terigu sebanyak $16 \%$

T3 : Tepung tulang ikan tuna mensubstitusi penggunaan tepung terigu sebanyak $24 \%$

\section{Tahapan Penelitian}

Proses penelitian dimulai dari proses pengumpulan limbah tulang ikan, kemudian dilanjutkan ke tahap pembuatan tepung tulang ikan, baik patin maupun tuna. Setelah tepung tulang ikan selesai dibuat, dilakukan uji rendemen terhadap tepung yang dihasilkan. Kemudian, proses pembuatan cookies dimulai dengan menggunakan formulasi yang terdapat pada Tabel 1. Setelah cookies selesai dibuat, uji hedonik, perhitungan kadar kalsium, dan uji daya simpan terhadap cookies pun dilakukan. Proses penelitian secara keseluruhan diilustrasikan pada diagram alir yang terdapat pada Gambar 1.

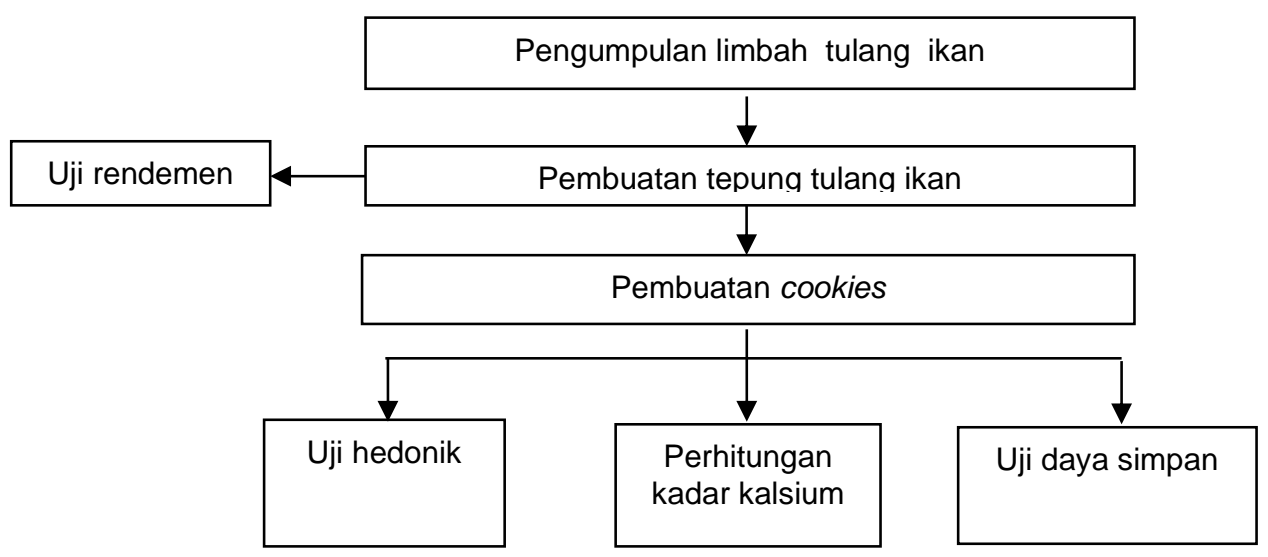

Gambar 1. Diagram Alir Proses Penelitian Keseluruhan 


\section{Proses Pembuatan Tepung Tulang Ikan}

Proses dilakukan berdasarkan penelitian Darmawangsyah, Jamaluddin, dan Kadirman (2018) yang telah dimodifikasi. Selama 30 menit, tulang ikan direbus pada suhu $\pm 80^{\circ} \mathrm{C}$, kemudian ditiriskan. Tulang ikan yang telah ditiriskan, dicuci menggunakan air bersih yang mengalir untuk memisahkan daging ikan yang masih melekat di tulang. Tulang ikan kemudian dijemur dengan menggunakan sinar matahari selama 5 jam, selanjutnya dilunakkan menggunakan panci presto selama 2 jam. Tulang ikan yang telah di-presto kemudian dicuci dengan air mengalir untuk menghilangkan lemak yang masih menempel pada tulang ikan. Proses selanjutnya, tulang ikan dikeringkan menggunakan oven pada suhu $125^{\circ} \mathrm{C}$ selama $1.5 \mathrm{jam}$. Tulang ikan yang sudah kering dihaluskan dengan menggunakan blender, lalu disaring dengan ayakan ukuran 80 mesh. Tepung tulang ikan disimpan dalam plastik standing pouch sebagai bahan pembuatan cookies.

\section{Proses Pembuatan Cookies}

Proses pembuatan cookies dari tepung tulang ikan dilakukan berdasarkan penelitian Hapsoro, Dewi, dan Amalia (2017) yang telah dimodifikasi. Proses pembuatan cookies terdiri dari 7 tahapan proses, yang terdiri dari: persiapan bahan, pencampuran bahan, pengadonan, pencetakan cookies, pengovenan, pendinginan cookies, dan pengemasan. Alur proses pembuatan cookies terdapat pada Gambar 2.

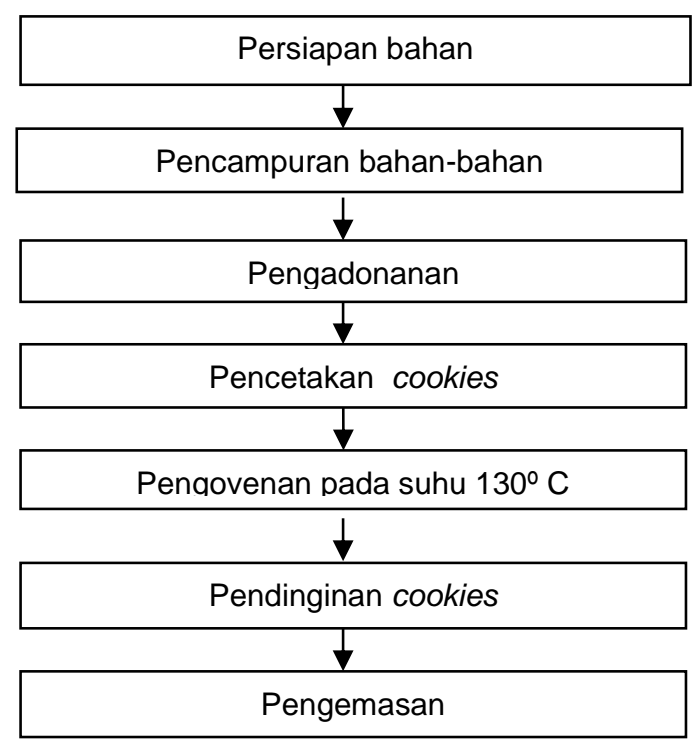

Gambar 2. Alur Proses Pembuatan Cookies Tulang Ikan

\section{Prosedur Analisis}

\section{Perhitungan Rendemen}

Proses perhitungan rendemen tepung tulang ikan dihitung dengan menggunakan persamaan di bawah ini:

\section{Uji Hedonik}

$$
\text { Rendemen }=\frac{\text { Berat tepung tulang ikan }(\mathrm{g})}{\text { Berat tulang ikan }(\mathrm{g})} \times 100 \%
$$

Sebanyak 25 orang panelis menilai setiap variasi cookies tulang ikan. Produk dan formulir uji hedonik terlebih dahulu disiapkan. Kemudian, panelis diberikan penjelasan terkait uji yang akan dilakukan, dengan menjelaskan mengenai urutan penilaian yang dilakukan, seperti warna, aroma, tekstur dan rasa. Selanjutnya, panelis melakukan uji hedonik tanpa membandingkan antar sampel dan melakukan pencatatan pada kertas yang sudah disediakan peneliti, dengan skala hedonik 1-9. Langkah yang sama diulangi untuk penilaian warna, aroma, tekstur dan rasa. Pengujian harus dilakukan secara berurutan agar hasil yang 
Pemanfaatan Tepung Tulang Ikan Patin dan Tepung Tulang Ikan Tuna - Pangestika, dkk Jurnal Pangan dan Agroindustri Vol. 9 No.1: 44-55, Jan 2021

diperoleh valid. Air putih diberikan kepada panelis agar penilaian tidak bias.

\section{Perhitungan Kadar Kalsium Cookies}

Perhitungan kadar kalsium hanya dilakukan pada dua variasi, yaitu P1 dan T1. Kedua variasi ini dipilih karena memiliki nilai hedonik paling tinggi setelah variasi tanpa penambahan tepung tulang ikan (K). Perhitungan kadar kalsium dalam adonan cookies P1 adalah sebagai berikut.

Tabel 2. Perhitungan Kadar Kalsium dalam Adonan Cookies P1

\begin{tabular}{|c|c|c|c|c|c|}
\hline No. & Jenis Bahan & $\begin{array}{l}\text { Kadar kalsium } \\
(\mathrm{mg} / 100 \mathrm{~g})\end{array}$ & Sumber & $\begin{array}{c}\text { Berat } \\
\text { Bahan } \\
\text { (g) }\end{array}$ & $\begin{array}{l}\text { Penyesuaian kadar } \\
\text { kalsium (mg) }\end{array}$ \\
\hline 1. & $\begin{array}{l}\text { Tepung tulang } \\
\text { ikan patin }\end{array}$ & $1002 \mathrm{mg}$ & $\begin{array}{l}\text { Afrinis, Besti, dan } \\
\text { Anggraini, (2018) }\end{array}$ & 20 & 200.4 \\
\hline 2. & Tepung terigu & $15 \mathrm{mg}$ & USDA (2019) & 230 & 34.5 \\
\hline 3. & Gula pasir & $5 \mathrm{mg}$ & $\begin{array}{c}\text { Kemenkes RI } \\
\text { (2018) }\end{array}$ & 180 & 9 \\
\hline 4. & Ekstrak vanili & $11 \mathrm{mg}$ & USDA (2019) & 5 & 0.55 \\
\hline 5. & Telur & $50 \mathrm{mg}$ & USDA (2019) & 55 & 27.5 \\
\hline 6. & Chocochips & $43 \mathrm{mg}$ & USDA (2019) & 100 & 43 \\
\hline 7. & Susu bubuk & $100 \mathrm{mg}$ & Putra (2013) & 25 & 25 \\
\hline 8. & Margarin & $20 \mathrm{mg}$ & USDA (2019) & 200 & 40 \\
\hline 9. & Baking powder & 5.876 & USDA (2019) & 5 & 0.2938 \\
\hline & & Total & & 820 & 380 \\
\hline
\end{tabular}

Dalam sekali proses, diperoleh berat total adonan sebesar $820 \mathrm{~g}$, apabila berat 1 pack cookies adalah $100 \mathrm{~g}$, maka jumlah pack yang diperoleh adalah sebanyak 8.2 pack. Kadar kalsium dalam 1 pack cookies dapat dihitung dengan persamaan di bawah ini.

Kadar kalsium cookies tulang ikan patin $(\mathrm{mg} / 100 \mathrm{~g})=\frac{\text { Jumlah kalsium pada semua bahan }}{\text { Jumlah pack dalam adonan }}$

Kadar kalsium cookies tulang ikan patin $=\frac{380 \mathrm{mg}}{8.2 \mathrm{~g}}$

Kadar kalsium cookies tulang ikan patin $=46.3 \mathrm{mg} / 100 \mathrm{~g}$

Setelah diperoleh kadar kalsium dalam adonan, yaitu sebesar $46.3 \mathrm{mg} / 100 \mathrm{~g}$, lalu dilakukan perhitungan kadar kalsium dalam cookies kering dengan pendekatan berat kering cookies. Kadar air dalam adonan cookies adalah 3\%, sehingga kadar kalsium pada cookies tulang ikan patin adalah sebesar $47.7 \mathrm{mg} / 100 \mathrm{~g}$.

Perhitungan kadar kalsium adonan cookies tulang ikan tuna dapat dilihat pada Tabel 4. Dalam sekali proses, diperoleh berat total adonan sebesar $820 \mathrm{~g}$, apabila berat 1 pack cookies adalah $100 \mathrm{~g}$, maka jumlah pack yang diperoleh adalah sebanyak 8.2 pack. Kadar kalsium dalam 1 pack cookies dapat dihitung dengan persamaan di bawah ini:

Kadar kalsium cookies tulang ikan tuna $(\mathrm{mg} / 100 \mathrm{~g})=\frac{\text { Jumlah kalsium pada semua bahan }}{\text { Jumlah pack dalam adonan }}$

Kadar kalsium cookies tulang ikan tuna $=\frac{956 \mathrm{mg}}{8.2 \mathrm{~g}}$

Kadar kalsium cookies tulang ikan tuna $=116.6 \mathrm{mg} / 100 \mathrm{~g}$

Setelah diperoleh kadar kalsium dalam adonan, yaitu sebesar $116.6 \mathrm{mg} / 100 \mathrm{~g}$, lalu dilakukan perhitungan kadar kalsium dalam cookies kering dengan pendekatan berat kering cookies. Kadar air dalam adonan cookies adalah 3\%, sehingga kadar kalsium pada cookies tulang ikan tuna adalah sebesar $120.2 \mathrm{mg} / 100 \mathrm{~g}$. 
Pemanfaatan Tepung Tulang Ikan Patin dan Tepung Tulang Ikan Tuna - Pangestika, dkk Jurnal Pangan dan Agroindustri Vol. 9 No.1: 44-55, Jan 2021

Tabel 3. Perhitungan Kadar Kalsium dalam Adonan Cookies T1

\begin{tabular}{cccccc}
\hline No. & Jenis Bahan & $\begin{array}{c}\text { Kadar kalsium } \\
(\mathbf{m g} / \mathbf{1 0 0} \mathbf{~ g})\end{array}$ & Sumber & $\begin{array}{c}\text { Berat } \\
\text { Bahan } \\
(\mathbf{g})\end{array}$ & $\begin{array}{c}\text { Penyesuaian } \\
\text { kadar kalsium } \\
(\mathbf{m g})\end{array}$ \\
\hline 1. & Tepung tulang ikan tuna & 3880 & $\begin{array}{c}\text { Bunta et al. } \\
(2013)\end{array}$ & 20 & 776 \\
2. & Tepung terigu & 15 & USDA (2019) & 230 & 34.5 \\
3. & Gula pasir & $5 \mathrm{mg}$ & Kemenkes RI & 180 & 9 \\
4. & Ekstrak vanili & $11 \mathrm{mg}$ & USDA (2019) & 5 & 0.55 \\
5. & Telur & $50 \mathrm{mg}$ & USDA (2019) & 55 & 27.5 \\
6. & Chocochips & $43 \mathrm{mg}$ & USDA (2019) & 100 & 43 \\
7. & Susu bubuk & $100 \mathrm{mg}$ & Putra (2013) & 25 & 25 \\
8. & Margarin & $20 \mathrm{mg}$ & USDA (2019) & 200 & 40 \\
9. & Baking powder & 5.876 & USDA (2019) & 5 & 0.2938 \\
\hline \multicolumn{7}{r}{} & Total & & 820 & 956 \\
\hline
\end{tabular}

\section{Uji Daya Simpan Cookies}

Cookies disimpan dalam kemasan berupa plastik PP standing pouch dengan ukuran $18 \times 29 \mathrm{~cm}$ dengan berat produk yaitu $50 \mathrm{~g}$. Penyimpanan dilakukan pada ruangan dengan suhu $\pm 27^{\circ} \mathrm{C}$ sampai $29^{\circ} \mathrm{C}$. Uji daya simpan dilakukan dalam kurun waktu 14 minggu, dengan frekuensi satu kali seminggu, dengan menggunakan uji sensori. Atribut sensori yang dinilai pada uji daya simpan cookies ini adalah kenampakan, aroma, tekstur, dan rasa.

\section{HASIL DAN PEMBAHASAN}

\section{Rendemen}

Rendemen pada pembuatan tepung tulang ikan patin adalah $38.6 \%$, sedangkan rendemen pada pembuatan tepung tulang ikan tuna adalah $43.6 \%$. Nilai rendemen pada pembuatan kedua jenis tepung tulang ikan ini lebih besar daripada rendemen tepung tulang ikan hasil penelitian Trilaksani et al. (2006), yaitu $28.85 \%$. Perhitungan rendemen dipengaruhi oleh metode perebusan yang digunakan dalam pembuatan tepung tulang ikan. Menurut Trilaksani et al. (2006), bahwa pada proses autoklafing dan frekuensi perebusan akan cenderung menurunkan rendemen. Hal ini mungkin disebabkan oleh larutnya komponen non mineral (air, protein, dan lemak) dalam bahan karena lamanya perebusan, sehingga dapat menurunkan rendemen tepung tulang. Selain itu, rendemen yang rendah juga dapat dipengaruhi oleh proses pengeringan yang dilakukan. Menurut pernyataan Nabil (2005), proses pengeringan pada pembuatan tepung tulang ikan dapat mempengaruhi nilai rendemen yang rendah.

\section{Uji Hedonik}

Uji hedonik pada cookies tulang ikan ini dilakukan untuk mengukur tingkat kesukaan konsumen ditinjau dari warna, aroma, tekstur dan rasa. Skala hedonic yang digunakan adalah skala 1-9, dengan spesifikasi seperti pada Tabel 4. Hasil penilaian dari uji hedonik dapat dilihat pada Tabel 5.

\section{Warna}

Menurut Kaya (2008), warna memberikan peranan penting pada suatu makanan. Warna adalah sifat sensoris utama yang dapat dilihat oleh panelis sehingga warna yang melenceng dari warna spesifik produk akan mempengaruhi tingkat selera panelis. Tingkat kesukaan panelis pada warna cookies dipengaruhi oleh penambahan tepung tulang ikan patin dan tuna.

Pada kategori warna, panelis memberikan penilaian terbaik pada cookies tanpa penambahan tepung tulang ikan (K). Sebaliknya, panelis memberikan penilaian terendah 
pada cookies P3 dan T3. Hal ini mungkin disebabkan karena cookies pada variasi ini berwarna lebih gelap dibandingkan yang tidak ataupun yang lebih sedikit ditambahkan tepung tulang ikan. Lebih gelapnya warna tersebut disebabkan oleh kandungan kalsium yang tinggi, sehingga akan menurunkan tingkat kecerahan warna cookies (Maulida, 2005). Sejalan dengan (Mervina, Kusharto, dan Marliyati (2012) dan Gobel, Naiu, dan Yusuf (2016) yang menyatakan semakin banyak substitusi yang digunakan, maka akan semakin menggelapkan warna cookies.

Tabel 4. Spesifikasi dari Skala Hedonik

\begin{tabular}{ll}
\hline Spesifikasi & Nilai \\
\hline Amat sangat suka & 9 \\
Sangat suka & 8 \\
Suka & 7 \\
Agak suka & 6 \\
Netral & 5 \\
Agak tidak suka & 4 \\
Tidak suka & 3 \\
Sangat tidak suka & 2 \\
Amat sangat tidak suka & 1 \\
\hline
\end{tabular}

Tabel 5. Hasil Uji Hedonik terhadap Setiap Variasi Cookies Tulang Ikan

\begin{tabular}{cccccccc}
\hline \multirow{2}{*}{ Penilaian } & \multirow{2}{*}{ K } & \multicolumn{3}{c}{ Tulang Ikan Patin } & \multicolumn{3}{c}{ Tulang Ikan Tuna } \\
& & P1 & P2 & P3 & T1 & T2 & T3 \\
\hline Warna & 7.7 & 7.4 & 7.2 & 6.8 & 7.1 & 6.3 & 6 \\
Aroma & 7.2 & 7.1 & 7 & 6.5 & 6.6 & 5.4 & 4.6 \\
Tekstur & 7.6 & 7.5 & 6.9 & 6.5 & 6.6 & 5.8 & 5.5 \\
Rasa & 7.6 & 7.5 & 6.9 & 6.0 & 7 & 6.3 & 5.5 \\
\hline
\end{tabular}

Keterangan :

K $\quad$ : Tanpa penambahan tepung tulang ikan sebagai substitusi

P1 : Tepung tulang ikan patin mensubstitusi penggunaan tepung terigu sebanyak $8 \%$

P2 : Tepung tulang ikan patin mensubstitusi penggunaan tepung terigu sebanyak $16 \%$

P3 : Tepung tulang ikan patin mensubstitusi penggunaan tepung terigu sebanyak $24 \%$

T1 : Tepung tulang ikan tuna mensubstitusi penggunaan tepung terigu sebanyak $8 \%$

T2 : Tepung tulang ikan tuna mensubstitusi penggunaan tepung terigu sebanyak $16 \%$

T3 : : Tepung tulang ikan tuna mensubstitusi penggunaan tepung terigu sebanyak $24 \%$

\section{Aroma}

Menurut Winarno (2002), aroma pada makanan dapat menentukan kelezatan tersendiri bagi penikmatnya. Aroma lebih dipengaruhi oleh indera penciuman. Pada umumnya, aroma yang dapat diterima oleh hidung ada empat macam, antara lain: harum, asam, tengik, dan hangus. Bau tersebut kemudian disalurkan ke otak, sehingga otak dapat menghasilkan beberapa macam bau dari keempat campuran bau pokok tersebut. Dari Tabel 5 dapat dilihat bahwa cookies yang paling digemari oleh panelis adalah cookies tanpa penambahan tepung tulang ikan (K), dengan skor 7.2. Setelah cookies K, variasi yang cukup digemari oleh panelis dari segi aroma adalah variasi P1, dengan skor 7.1. Menurut Kaya (2008), tepung tulang ikan patin yang ditambahkan ke dalam biskuit tidak memberikan efek yang nyata terhadap aroma karena tepung tulang ikan patin tidak berbau amis, sehingga disukai oleh panelis.

Terlalu banyak tepung tulang ikan yang ditambahkan sebagai substitusi akan berpengaruh pada aroma yang semakin menonjol dan tajam, seperti hal nya pada variasi P3 dan T3. Variasi T3 memiliki nilai hedonik yang lebih rendah dari segi aroma daripada variasi P3, sehingga variasi ini lebih tidak disukai oleh konsumen.

\section{Tekstur}

Menurut panelis, tekstur cookies yang terbaik adalah tekstur yang renyah dan lembut 
saat dikunyah. Cookies yang dapat mewakili tekstur ini ada pada cookies $\mathrm{K}$ dan cookies $\mathrm{P} 1$, dengan skor 7.6 dan 7.5. Cookies dengan substitusi tepung tulang ikan sebanyak $16 \%$ (P2, T2) dan 24\% (P3, T3) memiliki tekstur yang keras, sehingga lebih tidak disukai. Hal ini mungkin disebabkan tekstur tepung tulang ikan yang keras, sehingga apabila tepung tulang ikan yang ditambahkan semakin banyak, maka akan sangat berpengaruh ke dalam tekstur cookies yang menjadi keras juga. Hal ini sesuai dengan penelitian Pratama, Rostini, dan Liviawaty (2014) bahwa nilai kekerasan suatu biskuit yang semakin meningkat akan menurunkan tingkat kerenyahannya. Najibullah, Agustini, dan Wijayanti (2013) juga menyatakan bahwa penambahan tepung tulang ikan pada suatu produk olahan dapat menaikkan nilai kekerasannya. Hal ini disebabkan oleh kadar abu yang tinggi pada tepung tulang ikan, yaitu 75\% (Hemung, 2013). Daya tahan adonan terhadap pengembangan dapat menurun apabila kadar abu terlalu tinggi (Ningrum, 1999; Sulaswatty, Idiyanti, dan Susilowati, 2001). Secara keseluruhan, tekstur cookies tulang ikan tuna lebih tidak disukai oleh panelis daripada cookies tulang ikan patin.

\section{Rasa}

Substitusi tepung tulang ikan pada tepung terigu mempengaruhi penilaian panelis terhadap cookies. Formulasi rasa terbaik diketahui terdapat pada cookies $\mathrm{K}$, lalu disusul dengan cookies P1, yaitu masing-masing sebesar 7.6 dan 7.5. Secara keseluruhan, cookies dengan penambahan tepung tulang ikan tuna memiliki penilaian rasa yang lebih rendah, karena rasa tulang ikannya yang menonjol.

Semakin banyak tepung tulang ikan yang dimasukkan, maka rasa berkapur akan semakin terasa. Menurut Kaya (2008), perbedaan rasa pada setiap formula dipengaruhi oleh jumlah kalsium yang ditambahkan pada cookies sehingga mengakibatkan after taste yaitu sedikit berasa berkapur. Hal ini didukung oleh Sari, Dewita, dan Sumarto (2018) yang menyatakan bahwa kandungan kalsium yang tinggi dari tepung tulang ikan patin yaitu $2,35 \%$ dapat menimbulkan after taste yang sedikit terasa berkapur pada cookies.

\section{Kadar Kalsium pada Cookies Tulang Ikan}

Kadar kalsium pada cookies ditentukan melalui pendekatan dari penjumlahan kandungan kalsium setiap bahan dalam pembuatan adonan cookies. Hasil akhir dari penjumlahan tersebut kemudian dibagi dengan berat kering cookies, sehingga diperoleh kandungan kalsium dalam cookies kering. Perhitungan kadar kalsium hanya dilakukan untuk variasi $\mathrm{P} 1$ dan $\mathrm{T} 1$, karena kedua variasi ini memiliki nilai hedonik yang cukup tinggi setelah perlakuan tanpa penambahan tepung tulang ikan (K).

Berdasarkan hasil perhitungan, diketahui bahwa kadar kalsium dalam cookies P1 adalah sebesar $47.7 \mathrm{mg} / 100 \mathrm{~g}$, sementara cookies T1 memiliki kalsium lebih besar $2.5 \mathrm{kali}$ lipat dari P1 yaitu, sebesar $120.2 \mathrm{mg} / 100 \mathrm{~g}$. Kedua nilai ini masih lebih sedikit daripada kalsium pada cookies yang menggunakan tulang ikan gabus, yaitu sebesar $341.7 \mathrm{mg} / 100 \mathrm{~g}$ (Silviani, 2015). Kandungan kalsium cookies yang dibuat dalam penelitian ini juga lebih rendah daripada kandungan kalsium pada cookies tepung tulang ikan tuna yang dibuat oleh Karlinda (2018), yaitu $17.82 \%$. Hal ini mungkin disebabkan karena jenis tulang ikan yang digunakan berbeda dan perhitungan kadar kalsium dilakukan pada variasi penambahan tepung tulang ikan sebagai substitusi paling kecil yaitu 8\%, dengan penambahan tepung sebanyak $20 \mathrm{~g}$ ke dalam adonan. Sementara, Silviani (2015) menambahkan tepung tulang ikan gabus sebanyak $24.85 \mathrm{~g}$. Kemungkinan lainnya yang menjadi penyebab berbedanya kandungan kalsium pada cookies adalah komponen penyusun cookies dan berat bahan penyusun cookies yang berbeda antara penelitian ini dan penelitian yang dilakukan oleh Silviani (2015) dan Karlinda (2018).

\section{Uji Daya Simpan Cookies}

Uji daya simpan dilakukan untuk mengetahui berapa lama produk dapat bertahan kemasan standing pouch. Berikut adalah data pengamatan uji daya simpan pada cookies dengan menggunakan parameter sensori seperti pada Gambar 3 dan Gambar 4. 
Menurut Baigrie (2003), untuk mendeteksi off flavor dari suatu produk dapat menggunakan uji sensori agar menghasilkan respon yang lebih cepat. Kualitas sensori makanan berprotein dapat berkurang drastis selama penyimpanan dengan minimal terjadi perubahan zat gizi. Dari data yang terdapat pada Gambar 3 dan Gambar 4, dapat dilihat bahwa dari minggu ke-1 hingga minggu ke-5, seluruh penilaian sensori memiliki nilai yang sama. Artinya, cookies masih memiliki warna, tekstur, bau, dan rasa yang sama dari minggu pertama hingga minggu kelima. Skor penilaian ini mulai menurun pada minggu ke-6, untuk kategori tekstur. Skor penilaian bau dan rasa mulai sedikit menurun pada minggu ke-7 hingga minggu ke-9. Setelah minggu ke-10 penilaian tekstur, bau dan rasa menunjukkan tren yang semakin menurun, namun kembali datar dari minggu ke-11 hingga minggu ke-14. Walaupun skor penilaian sensori sedikit menurun hingga minggu ke-14, namun produk masih dapat diterima dan layak konsumsi.

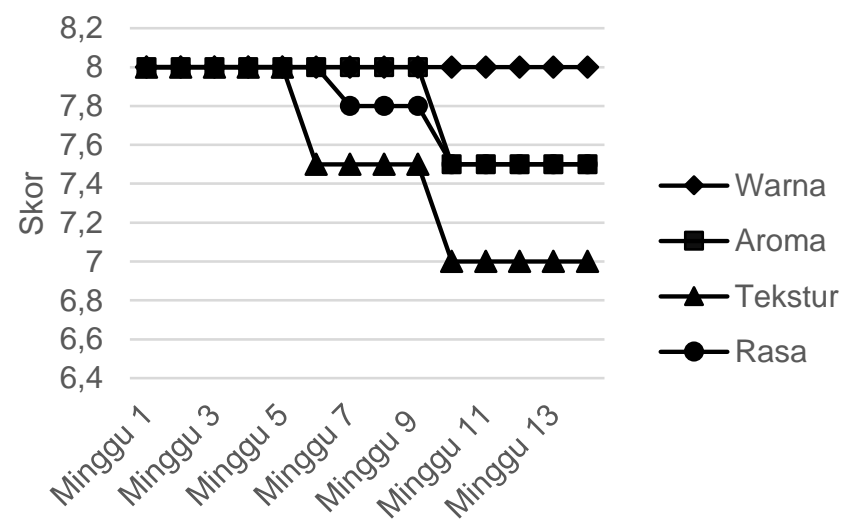

Gambar 3. Hasil Uji Daya Simpan Cookies Tulang Ikan Patin

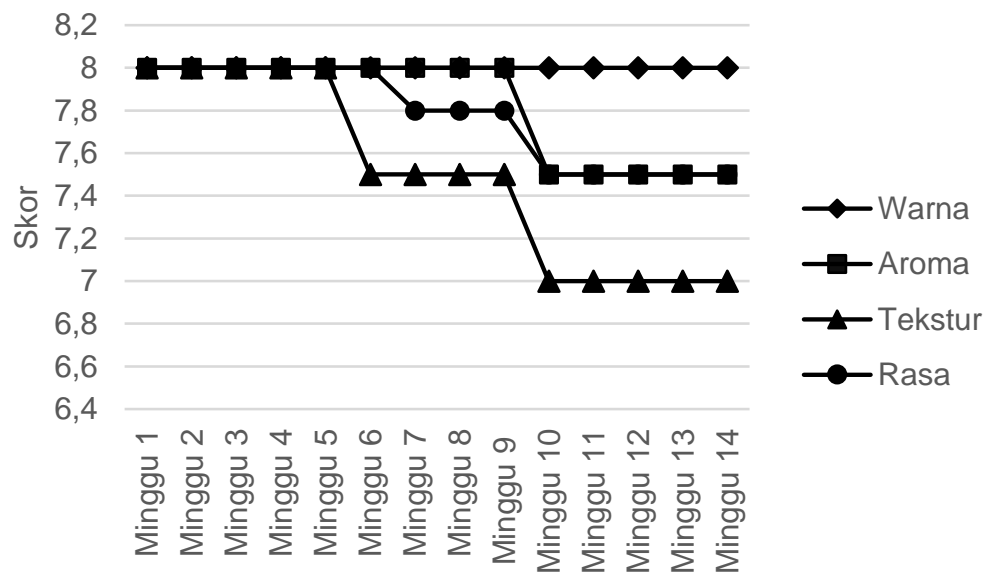

Gambar 4. Hasil Uji Daya Simpan Cookies Tulang Ikan Tuna

Pada Gambar 3 dan Gambar 4 terlihat bahwa skor penilaian sensori terhadap uji daya simpan cookies tulang ikan patin dan cookies tulang ikan tuna tidak memiliki perbedaan sama sekali. Berikut adalah uraian dari setiap parameter sensori:

\section{Kenampakan}

Kenampakan yang dilihat dalam uji sensori yaitu warna dan proses pertumbuhan jamur pada cookies tulang ikan. Hasil dari pengamatan mengenai warna pada cookies sampai minggu ke-10 belum ada perubahan warna. Warna masih tetap sama yaitu kuning keemasan dan coklat keemasan. Dari hasil tersebut dapat dilihat bahwa uji daya simpan tidak berpengaruh terhadap warna pada cookies. Biasanya warna pada cookies dipengaruhi oleh proses pengolahan seperti pengovenan dan penambahan tepung tulang ikan. Hal 
tersebut sesuai dengan pernyataan Rukmi (2011), warna pada cookies tidak dipengaruhi oleh proses penyimpanan, melainkan faktor pengolahan, seperti: kondisi oven dan waktu pemanggangan lebih memiliki efek terhadap warna produk.

Pertumbuhan jamur pada cookies pada minggu ke-14 masih belum terlihat. Hasil pengamatan masih tetap sama berada pada skor 8 yaitu dengan kondisi cookies masih baik dan belum ada jamur yang tumbuh pada cookies. Hal ini terjadi karena cookies bersifat kering sehingga jamur akan lama tumbuh pada tempat yang mempunyai kelembaban yang rendah. Selain itu, cookies disimpan di dalam kemasan, sehingga dapat mencegah masuknya uap air ke kukis. Bahan yang kering biasanya bersifat higroskopis, mudah menyerap air, namun apabila disimpan dalam kemasan, maka proses penyerapan uap air dapat diperlambat. Roosheroe, Sjamsuridzal, dan Oetari (2018) menyatakan bahwa proses pertumbuhannya jamur membutuhkan air dan oksigen sehingga, akan sulit bagi jamur untuk tumbuh di media yang kering atau minim air.

\section{Aroma}

Hasil penilaian terhadap aroma yang dihasilkan selama 14 minggu penyimpanan yaitu masih seperti aroma khas cookies dan belum ditemukan adanya tanda-tanda bau ketengikan pada cookies. Selain itu, dengan perbedaan penambahan persentase tepung tulang ikan ternyata juga belum mempengaruhi terhadap bau tengik pada cookies tulang ikan. Pada Gambar 3 dan 4, terlihat bahwa penilaian bau berada di angka 8 pada minggu ke-1, kemudian skor berkurang pada minggu ke-10 hingga minggu ke-14 menjadi 7.5, sehingga dari data tersebut dapat dilihat bahwa selama 14 minggu penyimpanan, aroma cookies belum mengalami perubahan yang signifikan. Meskipun demikian, terdapat penurunan skor sebesar 0.5 dari awal minggu penyimpanan hingga akhir. Penurunan nilai aroma mungkin dipicu oleh faktor kemasan yang digunakan. Aroma pada cookies juga berkaitan dengan kadar air. Kadar air dapat dipengaruhi oleh lama penyimpanan, permeabilitas kemasan dan volume gas dalam kemasan, sehingga kualitas cookies juga akan terpengaruh (Rukmi, 2011).

Tekstur

Persentase perubahan tingkat kerenyahan pada cookies tulang ikan selama penyimpanan cenderung menurun daripada saat awal penyimpanan, menjadi semakin tidak renyah. Hal tersebut dapat dilihat dari skor awal 8 dan semakin menurun menjadi 7.5 pada minggu ke-6. Nilai ini menurun kembali pada minggu ke-10 menjadi 7. Menurut Solihin, Muhtarudin, dan Sutrisna (2015), kerenyahan pada produk berubah dari tekstur yang cukup padat menjadi lebih lunak. Hal ini karena selama penyimpanan terjadi penyerapan air dari lingkungan ke dalam produk, sehingga pemuaian terjadi dan rongga di dalam produk meningkat.

Rasa

Penurunan rasa pada cookies diduga akibat penambahan tepung tulang ikan pada cookies, sehingga pada penyimpanan minggu ke-7, penilaian rasa sedikit menurun meskipun tidak secara signifikan, yaitu menjadi 7.8. Mulai minggu ke-10 hingga minggu ke14, skor rasa mulai mengalami penurunan lagi menjadi 7.5. Pada minggu ini, rasa amis pada cookies dengan penambahan tulang ikan patin maupun tuna mulai muncul. Pernyataan tersebut dapat dilihat dari grafik uji daya simpan dari skor 8 menurun menjadi skor 7.5.

\section{SIMPULAN}

Rendemen yang diperoleh dalam pembuatan tepung tulang patin yaitu $38.6 \%$ dan tepung tulang ikan tuna sebanyak $43.6 \%$. Cookies yang paling disukai panelis pada uji hedonik adalah cookies tanpa penambahan tepung tulang ikan (K), dengan rata-rata 7.5. Melalui perhitungan, diperoleh kadar kalsium pada cookies ikan patin (P1) dan cookies ikan 
tuna (T1) adalah $47.7 \mathrm{mg} / 100 \mathrm{~g}$ dan $120.2 \mathrm{mg} / 100 \mathrm{~g}$. Faktor penyimpanan dapat berpengaruh pada kenampakan (warna dan jamur), aroma (bau tengik), tekstur, dan rasa pada cookies tulang ikan. Dengan menggunakan uji sensori, hingga minggu ke-14, cookies masih bisa dikonsumsi karena belum ditemukan adanya tanda-tanda perubahan secara signifikan.

\section{DAFTAR PUSTAKA}

Adawiyah, A. R., \& Selviastuti, R. (2014). Serburia Suplemen Tulang Ikan Bandeng dengan Cangkang Kapsul Alginat Untuk Mencegah Osteoporosis. Jurnal IImiah Mahasiswa, 4(1), 53-58.

Afrinis, N., Besti, V., \& Anggraini, H. D. (2018). Formulasi dan Karakteristik Bihun Tinggi Protein dan Kalsium dengan Penambahan Tepung Tulang Ikan Patin (Pangasius Hypopthalmus) Untuk Balita Stunting. Media Kesehatan Masyarakat Indonesia, 14(2), 157. https://doi.org/10.30597/mkmi.v14i2.3984

Alaska, I. S. of. (2002). Analysis of Fish Meal. Alaska: Inc. Kodiak.

Baigrie, B. (Ed.). (2003). Taints and Off-Flavours in Foods. Cambridge: Woodhead Publishing.

Darmawangsyah, D., Jamaluddin P, J. P., \& Kadirman, K. (2018). Fortifikasi Tepung Tulang Ikan Bandeng (Chanos chanos) Dalam Pembuatan Kue Kering. Jurnal Pendidikan Teknologi Pertanian, 2(2), 149-156. https://doi.org/10.26858/jptp.v2i2.5170

Deswita, N. C., \& Fitriyani, E. (2019). Kadar Kalsium dan Mutu Hedonik Donat yang Ditambahkan Tepung Kalsium Tulang Ikan Tongkol (Euthynnus affinis). Jurnal IImu Perikanan Octopus, 8(1), 13-19.

Gobel, R. Van, Naiu, A. S., \& Yusuf, N. (2016). Formulasi Cookies Udang Rebon. Jurnal IImiah Perikanan Dan Kelautan, 4(3), 107-112.

Hapsoro, M. T., Dewi, E. N., \& Amalia, U. (2017). Pengaruh Penambahan Tepung Cangkang Rajungan (Portunus pelagicus) dalam Pembuatan Cookies Kaya Kalsium. Jurnal Pengolahan Dan Bioteknologi Hasil Perikanan, 6(3), 20-27.

Hemung, B.-O. (2013). Properties of Tilapia Bone Powder and Its Calcium Bioavailability Based on Transglutaminase Assay. International Journal of Bioscience, Biochemistry and Bioinformatics, 4(3), 306-309. https://doi.org/10.7763/IJBBB.2013.V3.219

Karlinda. (2018). Analisis Kandungan Zat Gizi Biskuit Crackers Tulang Ikan Tuna (Thunnus sp.) sebagai Alternatif Perbaikan Gizi Masyarakat. UIN Alauddin Makassar.

Kaya, A. O. W. (2008). Pemanfaatan Tepung Tulang Ikan Patin (Pangasius sp) sebagai Sumber Kalsium dan Fosfor dalam Pembuatan Biskuit. IPB (Bogor Agricultural University).

Lekahena, V., Nur Faridah, D., Syarief, R., \& Peranginangin, R. (2014). Karakterisasi Fisikokimia Nanokalsium Hasil Ekstraksi Tulang Ikan Nila Menggunakan Larutan Basa dan Asam. Jurnal Teknologi Dan Industri Pangan, 25(1), 57-64. https://doi.org/10.6066/jtip.2014.25.1.57

Lestari, W. A., \& Dwiyana, P. (2016). Pemanfaatan Limbah Tulang Ikan Tuna (Thunnus Sp) dalam Bentuk Tepung pada Pembuatan Stick. Jurnal Ilmu Kesehatan, 8(2), 46-53.

Maulida, N. (2005). Pemanfaatan Tepung Tulang Ikan Madidihang (Thunnus Albacares) sebagai Suplemen dalam Pembuatan Biskuit (Crackers). Bogor Agricultural University.

Mervina, Kusharto, C. M., \& Marliyati, S. A. (2012). Formulasi Biskuit dengan Substitusi Tepung Ikan Lele Dumbo (Clarias gariepinus) dan Isolat Protein Kedelai (Glycine max) sebagai Makanan Potensial untuk Anak Balita Gizi Kurang. Jurnal Teknologi Dan Industri Pangan, 23(1), 9-16.

Nabil, M. (2005). Pemanfaatan Limbah Tulang Ikan Tuna (Thunnus Sp.) sebagai Sumber Kalsium Dengan Metode Hidrolisis Protein. Bogor Agricultural University.

Najibullah, M. R., Agustini, T. W., \& Wijayanti, I. (2013). Pengaruh Tepung Karagenan terhadap Mutu Naget Ikan Bandeng (Chanos chanos) yang Ditambahkan Tepung Tulang Ikan Bandeng. Jurnal Pengolahan Dan Bioteknologi Hasil Perikanan, 2(3), 
$152-161$.

Ningrum, E. N. (1999). Kajian Teknologi Pembuatan Tepung Ubi Jalar Instan Kaya Provitamin A. Institut Pertanian Bogor.

Pratama, R. I., Rostini, I., \& Liviawaty, E. (2014). Karakteristik Biskuit dengan Penambahan Tepung Tulang Ikan Jangilus (Istiophorus Sp.). Jurnal Akuatika, 5(1), 30-39.

Putra, S. R. (2013). Pengantar IImu Gizi dan Diet. Yogyakarta: D-Medika.

Rahmawati, W. A., \& Nisa, F. C. (2015). Fortifikasi Kalsium Cangkang Telur pada Pembuatan Cookies (Kajian Konsentrasi Tepung Cangkang Telur dan Baking Powder). Jurnal Pangan Dan Agroindustri, 3(3), 1050-1061.

Roosheroe, I. G., Sjamsuridzal, W., \& Oetari, A. (2018). Mikologi: Dasar dan Terapan (Cetakan Ke). Jakarta: Yayasan Pustaka Obor Indonesia.

Rukmi, A. (2011). Pengaruh penyimpanan terhadap mutu biskuit yang diperkaya dengan tepung Ikan Lele Dumbo (Clarias gariepinus) dan isolat protein Kedelai (Glycine max). IPB (Bogor Agricultural University).

Sari, C. K., Dewita, \& Sumarto. (2018). Pengaruh Penambahan Tepung Tulang Ikan Berbeda (Lele, Patin, Sembilang) Terhadap Karakteristik Mutu Cookies. Jurnal Online Mahasiswa Fakultas Perikanan Dan IImu Kelautan Universitas Riau, 5, 1-9.

Silviani, D. (2015). Formulasi Cookies dengan Substitusi Tepung Tulang Ikan Gabus (Channa striata) sebagai Camilan Tinggi Kalsium bagi Anak Sekolah. Bogor Agricultural University (IPB).

Soekirman. (2004). Prosiding Widyakarya Nasional Pangan dan Gizi VII, Ketahanan pangan dan Gizi di era otonomi daerah dan globalisasi jakarta 17-19 Mei 2004 Soekirman. 599. Jakarta: Persagi, Pergizi-Pangan, dan PDGMI 2004.

Solihin, Muhtarudin, \& Sutrisna, R. (2015). Pengaruh Lama Penyimpanan terhadap Kadar Air Kualitas Fisik dan Sebaran Jamur Wafer Limbah Sayuran dan Umbi-umbian. Jurnal IImiah Peternakan Terpadu, 3(2), 48-54. https://doi.org/10.23960/jipt.v3i2.p\%25p

Sulaswatty, A., Idiyanti, T., \& Susilowati, A. (2001). Pemanfaatan Tepung Non Terigu sebagai Substitusi Tepung Terigu dalam Pembuatan Cookies dan BMC. Institut Pertanian Bogor.

Tababaka, R. (2004). Pemanfaatan Tepung Tulang Ikan Patin (Pangasius sp.) Sebagai Bahan Tambahan Kerupuk. Institut Pertanian Bogor (IPB).

Trilaksani, W., Salamah, E., \& Nabil, M. (2006). Pemanfaatan Limbah Tulang Ikan Tuna (Thunnus sp.) sebagai Sumber Kalsium dengan Metode Hidrolisis Protein. Buletin Teknologi Hasil Perikanan, 9(2), 34-45. https://doi.org/10.17844/jphpi.v9i2.983

Winarno, F. G. (2002). Kimia Pangan dan Gizi. Jakarta: Gramedia Pustaka Utama.

USDA (United States Department of Agriculture). 2019. Daftar Kandungan Gizi Bahan Makanan (DKGBM). Terj. National Nutrient Database for Standard Reference. United States Department of Agriculture, dalam Andrafarm, t.t. Daftar Kandungan Gizi Bahan Makanan: Semua Makanan. Online. Sumber: http://www.andrafarm.com/ andra.php? i=daftar-usda, diakses pada tanggal 20 Mei 2020.

Kemenkes RI (Kementerian Kesehatan Republik Indonesia). 2018. Daftar Komposisi Pangan Indonesia (DKPI). Online. Sumber: https://www.panganku.org/id-ID/view, diakses pada tanggal 20 Mei 2020.

Bunta, D. I., Naiu, A. S., \& Yusuf, N. S. 2013. Pengaruh Penambahan Tepung Tulang Ikan Tuna terhadap Karakteristik Hedonik Kue Bagea Khas Gorontalo. Nikè: Jurnal IImiah Perikanan dan Kelautan, Vol. 1 (2), hal. 81-88 